\title{
Tax Administration Reform in Transition: The Case of Croatia
}

Ott, Katarina

Source / Izvornik: Occasional Paper Series, 1998, 2, 1 - 40

Journal article, Published version

Rad u časopisu, Objavljena verzija rada (izdavačev PDF)

https://doi.org/10.3326/ops.5

Permanent link / Trajna poveznica: https:/urn.nsk.hr/urn:nbn:hr:242:737384

Rights / Prava: Attribution-NonCommercial-NoDerivatives 4.0 International/ImenovanjeNekomercijalno-Bez prerada 4.0 međunarodna

Download date / Datum preuzimanja: 2023-04-26

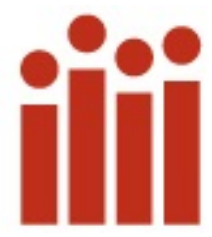

Repository / Repozitorij:

Institute of Public Finance Repository

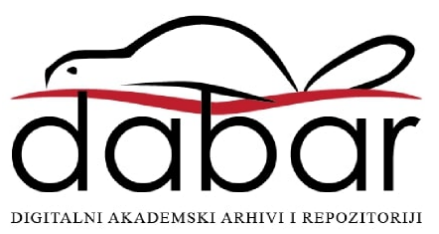




\title{
TAX ADMINISTRATION REFORM \\ IN TRANSITION: THE CASE OF CROATIA
}

\author{
Katarina Ott \\ Occasional Paper No. 5 \\ April 1998 \\ Institute of Public Finance \\ Katančićeva 5, 10000 Zagreb \\ CROATIA \\ tel: +38514819363 \\ fax: +38514819365 \\ ured@ijf.hr \\ (C) Institute of Public Finance 1998
}




\title{
TAX ADMINISTRATION REFORM IN TRANSITION: THE CASE OF CROATIA
}

\author{
Katarina Ott
}

This Occasional Paper reports the research results of a project on the tax administration in Croatia conducted by the Institute of Public Finance in Zagreb for the Croatian Tax Administration. The project team report was finalised in summer 1997 and it includes ten papers which are published in Croatian in the Institute's journal "Financijska praksa", Volume 22 , Number 1-2 (April 1998). This paper is the summary of the project written by Katarina Ott (Institute of Public Finance). 


\section{TAX ADMINISTRATION REFORM IN TRANSITION: \\ THE CASE OF CROATIA}

Katarina Ott

\section{ABSTRACT}

The paper discusses the basic issues of modern public administration in general and tax administration in particular, trends in their development and reforms in tax administrations. The main weight in reforms concerns problems of prevention of tax evasion, measures for making tax administration more efficient and reducing the complexity of taxation laws. Special attention is paid to tax administrations in transition countries with an emphasis on public officials, "big state", revenue collection problems and tax administration reforms. Particular problem of running the state in small countries is also discussed.

It can be concluded that modern tax administrations are concerned with a stronger focus on taxpayers, specialisation of personnel, independence from the ministries of finance and privatisation of those areas which could be better performed by the private sector. In order to accomplish the above mentioned goals, many countries have set in motion tax administrations reforms aimed at solving some of the key problems such as low salaries and the connected problem of attracting high quality personnel, corruption among tax administration personnel and complex and incomprehensible tax laws. Most reforms stress functional organisation of tax administration, organising a special customer service units and separate departments to deal with the largest enterprises. This should also reduce tax revenue collection costs and help to prevent tax evasion.

The extent to which Croatia, as a transition country, a small country and a country carrying out reform of its fiscal system (including tax administration reform), fits in with the processes described above is discussed in detail. Suggestions for further improvement of tax administration in Croatia are also given. 


\section{TAX ADMINISTRATION REFORM IN TRANSITION: THE CASE OF CROATIA}

The Republic of Croatia is currently engaged in reform of the overall fiscal system, including the tax administration reform. This paper analyses the extent to which reform in Croatian tax administration is in line with the theory and practice of tax administration in developed countries and countries in transition.

\section{Modern Public and Tax Administration}

Modern democratic societies need a modern, democratic public administration which will satisfy the public's requirements in the best possible manner. Public administration must continually undergo change and adjustment if it is to satisfy two opposite requirements. On one hand, it must be effective and efficient, which is achieved by implementing the same methods used in modern company management. On the other, it must satisfy the democratic requirements, fairness and justice and defend the achievements of civilisation.

In these two endeavours, the former is predictably more appealing to economists, especially American economists, while the latter is more attractive to lawyers, especially European lawyers. It seems that, at least for the time being, the former stream is more influential both in theory and in practice. The issues concerning tax administration are discussed in, for example. Jenkins (1994), Andic (1994), Tanzi and Pellechio (1995). The two prevailing streams mentioned above will not be discussed in this paper, in spite of their significance, because this subject is very well analysed in Koprić (1997*).

Public administration in modern societies offers services to citizens and in the process becomes more and more specialised. The time has gone when public servants had a general training and were capable of working in any area of public administration, and when their transfer from ministry to ministry was easy and painless. Speaking specifically of tax administration, Jenkins (1994) points out that it more closely resembles an institution for financial services than other public administration departments in charge of, for example, education or health service.

Tax administration must collect revenues in accordance with the law and, at the same time, provide an optimum public service. It must also pay attention to the administrative and compliance costs of taxation. In an attempt to meet these requirements, tax administrations are resorting more and more often to the implementation of principles and methods used in running a modern company. The notion that no tax reform can be successful without 
successful tax administration is becoming increasingly obvious, with the result that governments are starting to pay special attention to the improvements of tax administration.

The structure of tax administration must comply with relevant laws. An aspect that has lately become increasingly prominent is the need for greater independence and privatisation in tax administration. Independence of tax administration can be achieved by making tax administration financially and administratively independent of the ministry of finance, following the example of the central bank. In respect of privatisation, only those jobs within the administration are privatised which are held to be better performed by the private sector. The final goal is to offer a better service both to the state and to taxpayers. The advantages and defects of this approach are discussed in Koprić (1997*).

\section{Trends in Tax Administration}

As was outlined above, the general trends in reforms of tax administration are towards independence and professionalisation. (More on the issue, which will be only shortly outlined here, in Jenkins, 1994).

Tax administration is usually a part of public administration. Due to budget restrictions, those employed in public administration regularly earn less than those in the private sector. Low salaries can neither attract nor keep the high quality personnel. This is offset by the ability of some individuals to achieve compensation for their "services" or their ability of attaining information in their work in the public sector which may later be useful in the private sector. All forms of public administration offer the same opportunities, but nowhere to the extent as in tax administration.

This results in a rather widespread opinion among the public that tax administration is inefficient, incapable and corruptive. Once such opinion has taken roots, the tendency is to cut salaries even more, which leaves those employed even further behind the salaries received by the private sector. Governments are often fully aware of these circumstances and respond by turning a blind eye to a system of unofficial payments which allows tax administration to survive. This further decreases public revenue and increases costs for taxpayers who have to bear the additional burden of these non-formal outlays.

This results in a highly dangerous situation in which the public come to doubt the integrity and efficacy of the personnel, which directly influences their readiness to willingly pay taxes. The government's primary task should therefore be to reverse the process and make tax administration a professional organisation offering good salaries and attracting people. 
The administrative bodies of tax administration are often compared to central banks. But central banks are usually more efficient than tax administration. Young people prefer working for the central bank, the salaries are higher, the possibilities of advancement better, the equipment superior and more sophisticated, work conditions are better, etc. All these are reasons for the establishment of tax administration bodies independent of ministries of finance. This would encourage professionality or, more precisely (1) the rewarding and promotion of employees according to the responsibility of their job and their success in performing it; (2) a job classification system which clearly defines the responsibilities of each position; (3) independence from political influence and pressure enabling people to retain their jobs long enough to pay back their education; (4) setting up minimal conditions for each position and objective testing and (5) continuous education modified according and adjusted to the needs of each individual job position.

\section{Tax Administration Reforms}

During the last twenty years, tax system reforms have been carried out in almost all countries of the world. Reforms of tax administrations have been part of this more general reforms and improvements in administration have turned out to be among the most successful. (For details see Ott 1996).

Functions of tax administration

According to Tanzi and Pellechio (1995) the main tasks of tax administration involve: (1) information and instruction to taxpayers, (2) registration, organising and processing tax returns (input of data, processing declarations and payments), (3) coercive collection (closely connected with registration, accounting and return processing), (4) control and supervision (discovering lacking and insufficient tax returns and controls of books and papers in tax administration offices or business activities and books of taxpayers, while routine check-ups had already been done in the registration, accounting and return processing department), (5) legal services and complaints (taking cases to court, defending tax administration in court, explaining procedures which are or are not in accordance with the law). 
Inclination towards functional organisation of tax administration definitely prevails in modern theory and practice. This means introducing more specialised activities which give far better support to self-assessment of the taxation system. Tax administration develops around activities (such as calculation or supervision and control) and not according to the type of taxes or taxpayers. The main goal is to find the non-compliant. The majority of employees deals with exceptions and control and supervision of tax compliance. Such organisation requires self-control among personnel because working in one function serves to control the other.

Andic (1994) points out the following advantages of the functional organisation of tax administration:

(1) Productivity increases due to specialisation in particular fields like assessment, collection, supervision and control, coercive collection, etc. An officer does not have to know all the tax laws, or be responsible for tax assessment of the whole array of taxes relevant for a certain group of taxpayers in his competence. Special departments with specially trained personnel deal with new taxes, increased number of taxpayers, etc. Routine jobs can be performed by lower rank personnel, while specialists can concentrate on more complex tasks.

(2) Possibilities for checking and control are better. When the same tax officer is not in charge of processing all the tax elements of one taxpayer, any mistake made in one function (for example, tax assessment) will be more probably discovered in another (such as, for example, control).

(3) Effectiveness of operation increases. If a taxpayer, for example, does not comply with more than one type of tax, all taxes will be collected by one tax officer and not more of them.

Complexity of tax laws influences tax administration

Complexity is one of the main problems of modern tax systems (Owens and Whitehouse 1996). Tax laws are composed in such an awkward manner that taxpayers can hardly understand them and tax administrations have a hard time implementing them. This entails more and more complex forms of tax evasion, causing increased costs of tax collection for the state and increased compliance costs for taxpayers. More sophisticated tax evasion, on its part, also influences the complexity of the system since it entails more detailed legislature to cover all the holes in the laws. In Great Britain, for example, total administrative and compliance costs of taxation amount to about 1.5 per cent of GDP, with two thirds of the amount being at the expense of taxpayers (Sanford 1995). 
Taxation laws in the USA increased 200 per cent in the period from the ' $50 \mathrm{~s}$ to the '90s (Owens and Whitehouse 1996). In 1979, as many as 90 mil. taxpayers filled in their tax returns (as compared to 84 mil people voting in 1980) (Bawly 1982). Canada has trebled its taxation laws in the '90s with regard to the '70s and the Netherlands has doubled its. France is the only OECD country with the same number of taxation laws in the '90s as in the '60s.

Australia, Ireland and New Zealand have all initiated programmes for improvement of tax laws in order to reduce the compliance costs. The increase in tax administration is also influenced by the increase in tax burden (from 25 per cent in 1965 to 40 per cent in 1994 in the OECD countries), widening of tax base and increased contributions for social security (Owens and Whitehouse 1996).

Tax evasion is not always deliberate. According to the report of Cato Institute 1995, the majority of 40 mil. Americans "in direct conflict" with tax administration are simply confused by the complexity of tax return $(* * * 1996)$. The resentment towards taxation is so strong in the USA that a political party of taxpayers has almost nominated a famous Republican Pat Buchanan as its President candidate in the elections.

Basic elements of tax administration reform

Considering the basic elements of tax administration reform, Tanzi and Pellechio (1995) note the following requirements:

1. Firm and continuous political commitment. The process of reforming tax administration takes time and requires political support on the highest levels. Argentine President Menem and Minister Cavallo, for example, directly expressed their political support for tax reforms, which were initiated by tax administration personnel.

2. A staff capable of concentrated work over a long period. Ministers of finance cannot be daily involved in issues and problems arising from tax reform. They must delegate to specialists strategy planning, setting time limits for implementation, monitoring daily events, and decisions concerning transfer to less important jobs of personnel untrained for proposed changes and dismissal of any involved in corruption.

3. A well defined and appropriate strategy. No strategy is suitable for all countries. Reform of tax administration must adjust to local requirements such as a country's legal tradition in taxation system, local traditions, available personnel and resources. Copying foreign practice is a bad policy if insufficient attention is paid to one's own circumstances. The strategy chosen may be gradual or sudden, but it must definitely be 
simple and flexible, allowing deviations in case of unforeseen event. It must also set forth priorities and dead-lines.

4. Personnel training and education. Money is often spend in vain on extensive training. Instead of attempting to gain wide and general education, it would be wise to narrow it down to precise specialist qualifications.

5. Adequate funds for tax administration or at least transfer of people and resources. This involves firing and hiring, adequate and differentiated salaries, and shifting employees from low to high productive jobs. Tax administration can in this respect be regarded like a business which must maximise production, i.e. tax collection. The tax administration bodies must switch their organisation from being based on different types of taxes and taxpayers to being based on the key functions of tax administration.

6. Change in motivation of taxpayers and tax administration. A great deal of relevant literature deals with providing proper incentives for taxpayers. On the other hand, there is almost no literature at all concerned with incentives for tax administration personnel (motivating their effectiveness, rewarding honesty through higher salaries and promotion or submitting them to penalties and dismissal).

Main tasks of tax administration reform

The two main tasks of any tax administration reform are achieving higher effectiveness (capability to achieve high level of tax compliance) and efficiency (capability to make administrative costs per unit of tax revenue as small as possible). The goal is to coordinate effectiveness and efficiency because they can sometimes be contradictory. It would be highly useful, therefore, to point out special measures for the improvement of effectiveness and efficiency of tax administration

(1) Improving effectiveness

1. Voluntary tax compliance. The tax administration must acquaint taxpayers with various procedures for reducing the costs of tax compliance.

2. Principles of self-assessment and self-payment. These principles make effective tax administration and collection possible with a relatively small number of tax officers who have to cover a large number of taxpayers. 
3. Informing taxpayers. Tax administration must provide taxpayers with simple forms and clear and short information on tax returns. This is specially important when new laws are introduced (such as, for example, value added tax), when significant resources, and the time of senior public officials, must be invested in explaining taxes and tax liabilities.

4. Quick discovery of problems connected with tax returns and payment. It is extremely important to discover taxpayers who have not filed tax returns, who miscalculated their taxes or were late in paying tax. Tax administration must make sure that appropriate steps are taken in such cases. If there seems to be too many unregistered taxpayers, an investigation should be started. Tax inspectors could go from door to door checking shops, handicrafts workshops, etc. for proper registration. They could also check records of registered taxpayers to discover suppliers and buyers who are not registered as taxpayers.

5. Improvement in control and supervision. Taxpayers can evade taxes in ways which are difficult to discover. Thus more efficient control and supervision should be introduced. It is highly important that taxpayers believe that tax administration has complete control over everybody, including even the "biggest fishes". This will further stimulate their tax compliance. It should be suggested that inspection covers a far wider scope than it actually does. The programme must not be public and various circumstances may be given as reasons that might trigger control mechanism. The control and supervision programme, however, must clearly define subjects, time and the extent to which control and supervision will go.

6. Appropriate penalties. Contrary to the opinion that higher penalties entail less control, caution should be exercised here and penalties and control should be well co-ordinated. Too high penalties entail, among other things, an inclination towards bribing tax officers. It is therefore deemed wiser to use lower, but visible penalties, such as closing shops, workshops or coffee shops for a few days or weeks than to charge high penalties.

(2) Improving efficiency

Efficiency in tax administration is particularly stimulated by (1) establishing specials units for the largest enterprises, (2) defining the minimum threshold for certain taxes (like, for example, VAT), (3) alternate taxation for small taxpayers (annual payment, lumpsum taxation or tax assessment on purchases), (4) taxation at source, (5) using bank services for tax collection, etc. 
Of the above mentioned measures, the possibility of establishing special units for the largest enterprises should be specially emphasised. This unit should consist of leading experts in the field (highly professional and screened for corruption). It should control tax collection from the largest enterprises, which are small in number but nevertheless contribute the major part (sometimes more than 90 per cent) of VAT and profit tax. The largest enterprises also contribute a significant amount of income tax paid by their employees.

This special unit would guarantee timely collection of the greater part of tax revenue and also quick detection of unregistered and non-paid taxes, which would allow fast action and proper measures. It might also serve to redirect initial efforts in tax reform and introduce more effective procedures for the most important taxpayers instead of dealing with a large number of small taxpayers which bring small revenue. Several countries have conducted researches where new elements in tax administration were tested on such units, aimed at proving to bureaucrats who resisted change that improvements indeed were possible. New methods can later spread to other units of tax administration. Argentina, for example, started with the unit covering 1,000 of the biggest taxpayers at first to end up today monitoring about 200,000 taxpayers.

A special unit for the largest enterprises usually includes both tax collection and supervision. Supervision is of special importance here because large enterprises perform a great number of transactions, have complex business operations, a number of organisational units (sometimes even in foreign countries), highly educated and experienced accountants and lawyers, all of which enables them to resort to forms of tax evasion which are difficult to discover. For the same reason, they also require a special control unit consisting of highly professional and capable personnel. Dos Santos (in Tanzi and Pellechio, 1995) cites 26 countries with special units for largest enterprises, 17 of which are in charge of both supervision and collection, 1 of collection only and 8 of control and supervision only.

Special problem of tax evasion

The main aim of tax reform is to collect as high a revenue as possible. In order to achieve this, additional investment in tax administration and better prevention of tax evasion are essential.

It is not always easy to connect investment in tax administration with the effects achieved. As pointed out by Sanford (1997), expenditure on various customer service units, for example, may increase the costs of tax administration in the short run, but nevertheless 
reduce them in the long run. The calculation behind this approach is that a greater number of taxpayers can be expected to hand in properly completed tax returns if they can get advice and help. This investment can thus be regarded as the means for increasing revenue because taxpayers' opinion of tax administration will improve and they will comply with their tax liability more willingly. Additional investments in the service of coercive collection or supervision and control, on the other hand, can show their true face in a very short time.

About 800 mil. pounds was spent on the action Spend to Save in Great Britain in 1996. The greater part of the sum was earmarked for the prevention of tax evasion, but it is expected that about 200 mil pounds invested in tax revenue office will in the next three years bring back three times as much (with a thousand new inspectors and an additional thousand transferred from other jobs where they had become redundant due to computerisation). It is also expected that additional money in Customs and Excise will provide the same or even better results. It is obvious that investments in tax administration increase revenue collection, particularly if accompanied by an improvement in the effectiveness of control and supervision.

Concerning tax evasion, Sanford (1997) points out that it is particularly important to reduce possibilities for tax evasion and the net profit gained by it, and stimulate voluntary tax compliance:

(1) Reducing possibilities for tax evasion

(a) Collecting taxes at source (on salaries, dividends, interest) is the best solution. If that is not possible, a system of financial reporting should be devised which can be compared with tax declarations.

(b) The tax system should have as few exemptions, allowances and deductions as possible. Taxes should be elected which are more difficult to evade. Value added tax, for example, with its in-built control mechanism, is an example. It should, however, not have too many zero rates and different rates which again increase tax evasion possibilities.

(c) Tax administration must be honest since a corrupt tax administration stimulates tax evasion. This means a simple tax structure where tax officers have minimum discretionary authority.

(d) Assigning a special tax number to each taxpayer has proved a to be very useful device. Australia (where interest is taxable), for example, requires registration of one's tax 
number for every newly opened savings account. If this is not done, banks automatically deduct tax on interest at the highest rate. The same system is also in use in Latvia, where every taxpayer must be registered with the State Revenue Office and financial institutions are forbidden to open accounts either for individuals or companies without taxpayer number (World Bank 1996).

(2) Reducing net profit gained by tax evasion

Net profit gained by tax evasion is reduced if the ratio between risk and profit increases. To achieve this, control and supervision need to be intensified by giving maximum publicity to tax evasion prevention, increasing fines and sentences, and publicising at least figures if not names. Special attention should be paid to fines and sentences because overstressing them may lead to the feeling of resentment of tax administration and tax compliance.

(3) Reducing willingness to evade

Developing an increasing acceptance of taxation and tax administration, although slow, will reduce willingness to evade. It will involve:

(a)The state must create conditions for just and fair elections, equal implementation of laws for all, independence of courts, a cheap, quick and easily accessible system of complaints for everybody, and strong feeling of citizens' civic duty.

(b) Belief in the fairness of the system. Distrust of the government is very disruptive for tax compliance. If the state is perceived to be corrupt and wasteful (expensive buildings, cars, airplanes), if there is conviction that certain ethnic groups and economic classes fare better than other people in the distribution of state funds and that taxation is not sufficiently vertically or horizontally fair, etc., citizens are very likely to stop believing in their state. All that calls for constant refutation. The state must be seen to be just and fair. Lawbreaking and all violations must be punished severely. The state should report to the public regularly and in detail about its expenditures. Reducing costs of tax compliance is very important. The intention should be made public and borne in mind in every discussion about taxation policy. Revenue offices in Great Britain, New Zealand and Australia, for example, are obliged by law to prepare preliminary assessments on how each proposed change in the law will reflect upon the costs of tax compliance. 
(c) Relationship with tax administration. Special customer services units and special small business units are more and more founded within the tax administration. These services are well aware of the needs and problems of their customers. Taxpayers are approached as clients to be given assistance, innocent until proved guilty. Andic (1994) claims that such special services for help, information and education increase taxpayers's trust in tax system. Moreover, it leads to reducing compliance costs and improving the level of tax compliance. Information are not only given through the media, but in various publications, by phone, and in person. Systematic, simple and understandable literature on tax system, allowances, and detailed instructions on completing and filing tax return are imperative, together with direct help provided in completing tax returns. Sanford (1997) points out the special importance of an adequate complaints system. A Citizen's Charter Complaints Task Force was established in Great Britain in 1993. A complaints system must be easily accessible, widely known to the public, easy to understand and use, and quick in reaching timely decisions. It must also make clear to individuals the state of their case, ensure complete fairness of investigation, honour the principle of privacy, deal with all aspects of the problem, provide both answers and help, and inform the management, enabling it to improve its services. A special Adjudicator was appointed in Great Britain, first for the Inland Revenue and later on also for the Customs and Excise, and Contributions Agency. The adjudicator is not concerned with technical issues of taxation and tax compliance (which are in charge of a special complaints system), but deals with complaints against administrative bodies in revenue services.

In short, the most important preventive measures against tax evasion, according to Sanford, involve taxation at source whenever possible, a simple taxation system with minimum tax exemptions, an efficient supervision and control mechanism capable of achieving maximum revenue, a regular check on penalisation (especially during inflation) and adequate publicity in the case of stricter penalties, economical and fair public expenditures, just taxes, and fair, client-friendly tax administration.

\section{Tax Administration in Transition Countries}

Transition from a planned economy into a market one requires thorough examination of the role the state plays. World Bank (1996) points out that the role of the state must significantly decrease and the services offered by the state must become exceptions and not the rule. States must direct their efforts to stimulating macroeconomic stability and providing a legal and institutional environment stimulating the development of the private sector and of competition. Reforms of fiscal systems are undertaken with this specific aim 
in mind, meaning reforming or (in certain transition countries) only just introducing tax administrations.

Transition countries have to chose between the more liberal American style market economy and the more social market economy of Western Europe style. The issue boils down to offering the citizens a broader or narrower range of free education, health care and infrastructure or the choice between a greater or smaller degree of income redistribution. But no matter which road they take, all transition countries must improve the effectiveness and quality of their services and direct their efforts to achieving results put forward in state programmes and their costs. An especially important mission of transition states is education of the public on the need for and the process of reforms, including the reform of the state itself, and making their policies and decisions as clear as possible. Achieving agreement between politicians and as many citizens as possible on the need for reforms is imperative. Reform of the state is carried out together with the liberalisation of its economy. Some reforms can be accomplished quickly (like the withdrawal of the state from production) and some require long-term institutional changes and lag behind market liberalisation (like the improvement of tax administration).

Public officials in transition countries

The changed role and different running of the state involve changes in professional state administration. The World Bank (1996) experts estimate that public officials in transition countries are often concentrated in wrong public sectors. The state does not transfer its officials quickly enough to suit the changes of its functions. Officials often have the wrong education for jobs they perform, insufficient difference in salaries and other motivating elements are equally non-stimulating. Contrary to the general opinion, most transition countries do not have too many public officials, nor are they underpaid. Their distribution is simply extremely irrational.

World Bank (1996) shows that the data on state employees and their salaries are, generally speaking, in line with the same data in industrial countries. This means that there exists a drop in real wages and a growing gap between the salaries in the private and public sector. Especially alarming are the lack of employees and too low salaries in key areas such as customs and tax administration and police. The problem lies in the distribution of employees. Basic central and local administration bodies in transition countries are usually very small, while education, health care and other public services have too many employees. Usually, there are too few professionals and too many of other staff. Even where the average educational level is high, civil servants do not have sufficient 
accountancy, taxation, legal and other specialised knowledge about public administration required for the market economy. In addition, salaries in the public sector are seriously limited and effort and success at work hardly influence the amount earned or promotion possibilities. Instead, personal and political connections are still overstressed in making a career. It is therefore not surprising that public administration in many transition countries is drowned in low morale, absence from work, moonlighting, corruption and the exodus of the best workers into the private sector.

These problems cannot be solved overnight, but the direction of reforms is more than obvious. Salaries, hiring, advancement and firing in the public sector must be more flexible. Majority of privileges and payments in kind must be replaced by cash payments. Differences in salaries also must increase significantly. As a special imperative in transition countries, the state must de-politicise public services, introduce systematic standards for professional advancement in career and condition it by the acquisition of knowledge required in market economy. Employment of public officials must be carried out in accordance with the law on public officials salaries and budget plans.

The problem of the "big state" in transition countries

Transition countries are particularly inclined to "big states" which are expensive and difficult to finance. There is an attempt to solve the problem of insufficient state revenue in most of these countries through the improvement of taxation policy, particularly tax administration.

Reducing expenditures in states where public consumption is traditionally high and the population expect a wide range of public services is exceptionally difficult. It is especially dangerous that taxation itself is used for achieving various economic and social goals which only produces additional pressures for tax exemptions and lowered tax rates. Special problems present: tax collection from public companies which in fact have special deals with the state and coverage of the growing small private sector inclined to tax evasion.

Tax revenue collection in transition countries

According to World Bank (1996) among special taxation distortions in transition countries which can cause low revenue collection and complicate tax administration the following should be pointed out:

1. Basic rates are often very high, which stimulates tax evasion and unofficial economy. 
2. Dependency on income tax for financing social expenditures is too high. Income taxes usually imposed upon employers can hinder entrepreneurship, discourage regular employment and entail unofficial economy.

3. Numerous tax exemptions and different tax rates for various business activities.

Improvement of the tax revenue in transition countries requires reforms in tax structure and the taxation system, and also in revenue collection. In this respect, restricting tax exemptions and cancelling tax differences among the sectors is imperative. Value added tax must be applied on all goods and services, except imports, which is taxed at zero rate. Strategic goods like gas and oil must be taxed just like any other goods. Moreover, significant excises can be introduced on them. Income and profit tax deductions must be restricted in scope and agriculture "taken care of" (by eliminating tax exemptions first and then by introducing land charges). The total amount of profit, income, wages and value added taxes must be examined in order to improve tax efficacy and reduce tax evasion.

Effective tax administration in market economies is based on voluntary tax compliance by a large number of decentralised taxpayers. Transition countries are now only just beginning to pay attention to the importance of tax compliance and creating a modern tax administration capable of better and more efficient tax collection. Functional organisation, concentration on biggest enterprises and issuing tax numbers to taxpayers are highly recommended in this respect.

Control and collection also must be improved. Control should be carried out selectively, abandoning the principle of checking every taxpayer at regular intervals. Tax administration in transition countries must also be given stronger competence in coercive collection (ranging from sequestration to closing down companies).

\section{Reform of Tax Administration in Transition Countries}

Reform of tax administration in transition countries is usually carried out as a part of fiscal system reform. Countless texts and discussions have been written on the problem of forming institutions, property rights, transaction costs, etc., but hardly any practical analyses exist on the organisational aspect of public finance. The majority of literature in transition countries concerns policy and not organisation. Authors taking up organisational issues are few and rare (Tanzi, Jenkins, Sanford).

Tax administration in transition countries is usually organised according to types of taxpayers, taxes or economic sectors, which is exactly opposite from the usual approach in contemporary theory and practice. 
Andic (1994) points out that transition countries most definitely need changes in tax administration, and its adjustment to modern accounting, control, assessment, collection, coercive collection, compliant procedures and the growing number of individual taxpayers and private companies. He perceives the reorganisation in issues like the position of tax administration in the ministry of finance, internal organisation of tax administration and the order of changes as being of primary importance.

Experts are not unanimous regarding the location of tax administration. Some favour the approach that tax administration should be a part of the ministry of finance (for example, Casanegra, Silvani, Vehorn), while others are in favour of the independent tax revenue office with the status of ministry or body independent of ministry (Jenkins). Regardless of the differences in this respect, all (including Tanzi) are in favour of an effective and efficient tax administration.

Concerning internal reorganisation of tax administration, more or less everybody agree that it should be based on the functional principle (Andic 1994, Tanzi and Pellechio, 1995).

As far as the order of changes is concerned, priorities in reorganisation must first be established, such as the form of taxpayers registration, collection and accounting system, introducing suitable tax return forms, discovering offenders, choosing subjects to be controlled, employing new employees, their distribution into departments, location, education, etc. Organising special customer service units is usually recommended to take place in a relatively short time (six months), because this service, together with appropriate training of old and new tax officers, is expected to show results in shortest time possible.

Tax administration organisational change is expected to take a considerable time (up to two years). It must be carried out gradually, with special attention to strengthening leading capabilities on all levels.

Strengthening of tax administration will not result in higher revenue immediately, in the short term, but these steps nevertheless must be taken. Priorities must be given to the development of procedures for registration of taxpayers and tax return, to the process of payment, control over tax compliance and organisation of adequate training of tax officers. Increasing the level of information and education given to taxpayers is also very important, which calls for organising special taxpayer relation services within tax administration.

Reorganisation of the existing tax administration along the functional lines is a long, time consuming process which involves shifting employees into new departments, perceiving needs for opening new jobs, starting adequate training, developing the system of leading 
and internal control and planning computerisation. Organisation, however, can never be final and it should be able constantly to change and adapt.

To sum up, in order to collect sufficient revenue for financing public needs transition countries need to change the structure of tax administration, educate personnel and better inform and instruct taxpayers.

\section{Specific Problems of Running the State in Small Countries}

Having examined the theory and practice of tax administration in general and of tax administration in transition countries in particular, it will be interesting to consider some specific difficulties faced by small countries.

In his very interesting paper on how small countries are run, Harberger (1988) says that their main problem is usually that they have too few trained and experienced people to run the state properly. And he draws the line of a country qualifying to be a small country at a population of 20 million!

According to Haberger, a country of 6 mil. inhabitants (like Croatia) will have less than 1.2 mil. inhabitants older than 40 , and the number of the sufficiently educated will be less than 1 per cent of these. This educated elite is supposed to run the state and to fill positions of senior ministers, generals, colonels, judges and lawyers, accountants and auditors, tax-collectors and teachers and, of course, engineers, agricultural workers, etc.

Since this enormous responsibility rests on the shoulders of such a small number of people, the state should be as simple as possible (in its legal system, budget, taxation system, etc.). Everything should be as simple as possible, with as few exceptions as possible, and the usual trap of having administration with broad discretionary authorities must be avoided at all costs.

Due to the small number of people, organisation of small countries must make the best possible use of its human potentials. Policies must be simple, rules clear and easy to implement. The state must be just, equal for all and impersonal.

This requirement conceals what is predominantly a demographic problem. It is easy to have an impersonal state which implements rules in a big state. In small countries, however, with the total "elite" members numbering only a few thousands, this is extremely hard to achieve. The ruling class has family ties all over, many frequented the same schools, came from the same regions, etc.

Tax inspectors in small countries will be daily pestered by enquiries about the tax status of the members of their family, friends, schoolmates or relatives of their family and 
schoolmates. It is no wander then that nepotism and corruption emerge. In such conditions, people truly dedicated to reforms are more than likely to end up in total isolation. They will offend their families and friends and become objects of ridicule and derision. They could even lose their jobs and friends.

Solution to this problem is not simple. Small countries should develop a professional attitude, and introduce reforms which take into account their objective circumstances and do not attempt to introduce systems incompatible for the limited number of people to carry them out.

\section{Tax Administration in Croatia}

Having gone through tax administration in theory and practice of modern countries, with special emphasis on transition countries and small countries, the following conclusions can be reached:

The trend in modern tax administration is a strong focus on taxpayers, specialisation of personnel, independence from the ministry of finance and privatisation of activities which can be better performed by the private sector. In order to achieve the above mentioned goals, many countries have started reform of tax administrations aimed at solving some key problems, such as low salaries and resulting difficulties in attracting high quality personnel, corruption among the employees and complex and incomprehensible taxation laws. The majority of reforms stress functional organisation of tax administration, organising special public advice services, separate service for the largest enterprises, reducing costs of tax revenue collection and prevention of tax evasion.

To what extent does Croatia, as a small and transition country carrying out reform of fiscal system, including tax reform, fit into the processes described above?

If we read Croatian Law on Tax Administration carefully and compare it with similar laws in other countries and with basic recommendation of world experts, we must conclude that the Croatian Law repeats more or less all that is said in other laws and recommendations of relevant experts. Whether or not the comparison of Croatian practice and the practice of other countries would yield the same result, it is hard to say just now. One of the basic problems the Croatian taxpayer has to face is the fact that tax officers do not follow the laws all the time, but also resort to various rules and regulations, instructions and 
explanations which may, and just as easily may not, correspond fully with what is said in the law.

\section{(1) Focusing on taxpayers}

It is difficult to estimate the extent to which in practice the Croatian tax administration is focused on taxpayers, which is one of the elementary conditions of its effectiveness and efficiency. Such focusing is not indicated at all in the Law on Tax Administration. The only point that might suggest anything that could be considered as taxpayer friendly behaviour is Article 3, Paragraph 11 of the Law. It says that Tax Administration "is concerned with the development and improvement of the tax system." Concern about revenue collection and repressive action towards taxpayers are the only visible and predominant topics throughout the whole Law, with not a single reference to taxpayers being perceived as beneficiaries and without any reference to their rights. Zhe Law constantly mentiones only taxpayers duties. Analysis of Tax Administration jobs (Koprić 1997*) also shows that relations with taxpayers are hardly ever mentioned.

In its further development, the Croatian Tax Administration should, therefore, pay special attention to the following: (1) requiring in an official act polite and prompt communication of Tax Administration officers with taxpayers, (2) during the study Course in Taxation, special attention must be paid to educating students in the spirit of democratic principles and good relations with the public, and (3) organising special customer service unit at least on the level of the Central Tax Administration Office.

\section{(2) Specialised training for tax administration officers}

Croatian Tax Administration have inaugurated special Tax studies at the Zagreb Faculty of Law. In addition, specialisation have been conducted within the Tax Administration Office. Obviously, it is more important to improve the quality and expertise of employees than to enlarge their number. Following this line, Brčić and Jančiev $\left(1997^{*}\right)$ argue in favour of employing more personnel with graduate education and fewer with undergraduate qualifications only. It is difficult to say whether this is in accordance with the modern perception of the need for constantly greater specialisation of tax officers. Perhaps secondary (high) school qualifications might suffice for the majority of jobs in tax administration, with specialisation only for particular kinds of job. Arbutina (1997*) points out that Tax Administration should reduce the number of economists employed and 
increase the number of lawyers, which seems logical enough. Economists should predominate in drawing up and running the tax system. Lawyers should predominate in drafting laws, and controlling obeyance of regulations, dealing with complaints, etc.

Bearing in mind what has been said about specialisation, the following may be recommended: (1) institution of postgraduate studies in public finances, (2) continuous inservice training of tax officers, but not necessarily an increase in numbers, (3) fundamental, frequent and constant specialist education carried out separately for each type of job, (4) paying special attention to predominantly economic or legal education of personnel when employing new tax officers or shifting them to other jobs, depending on the requirements of the job in question.

\section{(3) Tax administration independence}

The issue of independence of the tax administration of/from the ministry of finance is not only of technical, but also of political nature. Croatian Tax Administration is neither independent, nor particularly autonomous. It is a part of the Ministry of Finance, does not have the status of legal body and is financed from the budget. Brčić and Jančiev (1997*) consider that it is not detrimental for Tax Administration to be part of the Ministry of Finance because this makes its co-operation easier with the Financial Police, Customs, etc. Financial dependence on the budget, however, causes considerable problems for tax administration. The salaries of its employees are restricted by the budget, which makes it difficult to attract and keep high quality experts and impossible to stimulate adequately their better performance at work.

Although modern literature is increasingly in favour of tax administration independence and its organisation on the same principles as independent central banks, this approach would be difficult to recommend for Croatia at this moment. Any more significant independence granted to tax administration would entail a higher level of democratisation in political system, with explicit mechanisms of democratic control which would prevent possibilities of making tax administration an instrument in the hands of political elite (see Koprić 1997* and Arbutina 1997*). The best recommendation, then, would be to leave the Tax Administration as a department within the Ministry of Finance for the time being, but also to continue developing its independence within the Ministry and, as Brčić and Jančiev $\left(1997^{*}\right)$ suggest, to let it keep a certain percentage of the tax collected. It would then be able to use its own funds for salaries and other stimulation at work or for investment in additional education and specialisation. 
Economic privatisation in Croatia has not yet gone very far. Not even big public companies have been privatised, let alone public administration, which is practically not even seriously considered yet. Croatian Tax Administration, however, could start thinking (as many tax administrations in other countries already have done) about the possibility of privatisation of certain of its activities which would be better performed by the public sector. Jurlina-Alibegović $\left(1997^{*}\right)$ points out the possibilities for privatisation in computer services, issuing and sending tax forms and reports on paid taxes, gathering, sending and filing in documents, correspondence with taxpayers, etc. Koprić $\left(1997^{*}\right)$, however, is more sceptical and warns against excessive privatisation which could work at the expense of citizens. Although privatisation is inevitable in the long run, Tax Administration should not be let slip back to tax farming, which would be a serious political and civic step backwards.

\section{(5) Low salaries in tax administration}

Tax administrations in almost all countries are faced with the restrictions arising from budget funds. Tax administration officers as a rule have low salaries, often significantly lower than the private sector. Due to this problem, tax administrations have a hard time in attracting highly educated and good workers. Croatia is no exception in this respect. Average salaries of tax officers lag behind salaries in the private sector. According to the level of salaries, Tax Administration occupies fifth place (among the organisations for which data are available), behind the inland service of the Ministry of Foreign Affairs, the Customs Office, the Ministry of Economy and the Ministry of Development and Reconstruction (see Koprić 1997*). There have recently been more and more requests that something should be done about the salaries because of the important role Tax Administration plays in revenue collection and thus in financing the state. Tax officers can be stimulated through higher salaries, further education, career prospects and impartiality in hiring (Arbutina 1997*), keeping a part of revenue collected which could be used for salaries, motivation at work and education (Brčić and Jančiev, 1997*) or through establishing a special fund for rewarding employees according to the results achieved (Bejaković 1997*). 
Low salaries in public administration, and especially in tax administration where officers have high discretionary authority is frequently a source and cause of corruption. This phenomenon is supposed to exist, but difficult to discover or prove. The public is usually very well tuned to listening to any such rumours and quick to draw conclusions on the quality of public administration. Public opinion plays an important role in forming acceptance of or aversion towards proper tax compliance. Croatia certainly is no exception in this respect. Štulhofer (1997) claims that as many as 75 per cent of respondents in a representative Croatian sample believe that all or almost all public servants are corrupt. Although this refers to all public servants and not only Tax Administration, and even though it need not be based on real facts, it should be constantly kept in mind. In order to prevent corruption and invalidate rumours about possible corruption, Tax Administration bodies should: (1) eliminate the high discretionary authority its officers have, (2) organise jobs along functional lines which allows transparency, (3) severely punish any irregularity in the work of its personnel, (4) do its best to improve the opinion of the public (through, for example, establishing customers service unit.

\section{(7) Complex and incomprehensible tax laws}

Complex and incomprehensible tax laws have been an increasing disease of modern taxation systems. Although one of the basic criteria in Croatian tax reform was simplicity (Rose and Wiswesser 1995), the new system is still rather complex, vague and imprecise (more about this in Ott 1996a). Arbutina (1997*) shows that in solving everyday problems of implementation of the new Croatian tax system, two specific institutions have emerged: the institution of opinions of the minister of finance and the institution of the Ministry of Finance rulings. Opinions of the minister result in inconsistency and violate legal safety. Rulings have in time turned into what they should not have been - an additional source of law which now violates legal safety and directly threatens legality. Koprić (1997*) points out that the Decree on the Internal Organisation of the Ministry of Finance has widened the range of Tax Administration activities by giving the minister of finance authority to expand jobs within the Tax Administration competence. The Central Tax Administration Office also passes implementation rules which are not in accordance with the Law on State Administration System. Doubtful solutions should, therefore, be examined and the institutions of advance ruling or letter ruling might be introduced as instruments of improving implementation of new rules and regulations. 
Functional organisation is favoured not only by foreign experts, but also by many Croatian ones (like Bejaković, Brčić and Jančiev, Jurlina-Alibegović, etc.). It is difficult to estimate whether Croatian Tax Administration is already organised, as some claim (Brčić and Jančiev 1997), on the functionality principle. The Central Office of Croatian Tax Administration is to a certain extent organised along the functional lines (especially its services for normative activity, administration procedure, control, etc.). When these services are divided in departments, however, this ceases to be functionality principle and becomes simple division of various taxes into appropriate departments. In local tax offices, jobs are divided among departments by the type of taxes and the number of taxpayers. In the Zagreb local tax office, however, functional departments have been organised (for assessing and monitoring taxes, reclamation and coercive collection, and control and supervision).

One of the reasons justifying the functionality principle is that it allows tax administration to primarily concentrate on (besides self-assessment) exceptions and controlling tax compliance. Tax Administration in Croatia seems, however, to be primarily engaged in the activities the taxpayers should be doing themselves. Brčić and Jančiev (1997*) claim that as many as 46.2 per cent of tax officers are engaged in tax assessment. Only 19.5 per cent of them are engaged in control activities in Croatia, even though the majority of tax officers should, in the normal course of taxation, be engaged in these activities. The results are even worse and more depressive if we look at the number of functions. Koprić (1997*), acknowledging but not taking into account the Financial Police, points out that only 9 per cent of all Croatian Tax Administration functions involve control functions.

Further possibilities for specialisation of jobs and services along the functional lines on all levels of Tax Administration should be investigated in more detail. The aim of the functionality principle in organisation is improvement in productivity, effectiveness, inspection and control.

\section{(9) Establishing special customer service unit}

It would not be fair to say that Croatian Tax Administration does anything but its best to keep taxpayers informed and instructed. When occasions dictate, taxpayers are informed about changes in the taxation system, deadlines, etc. through radio and television broadcasts and newspapers. In addition, departments for tax assessment and monitoring in regional offices are required to provide taxpayers with professional help and answer their 
inquiries. But, the modern practice of focusing on taxpayers has given rise to special customer service unit. This service should be for starter established at least in the Central Office and then at other levels as well. Its task would be to give as simple instructions as possible about the filling in and filing tax returns. Its aim would be improving public relations, increasing confidence and trust in taxation system and tax administration activities, reducing compliance costs and make the whole procedure simpler and easier.

(10) Establishing special service for the largest enterprises

The practice of other countries has shown that establishing special service for the largest enterprises can achieve excellent results in collection and inspection of taxpayers who bring in the major part of revenue. Such service is favoured also by some Croatian authors (for example, Brčić and Jančiev, Jurlina-Alibegović). It should first be organised in the Central Office and then at other levels of tax administration. It should bring together the most capable and experienced officers who should be well paid in order to avert the temptation of bribery. The results of control and supervision of few top taxpayers and beneficiaries should be bound to become visible very soon.

\section{(11) Decreasing tax collection costs}

Focus on taxpayers, reducing tax evasion, increasing tax administration effectiveness and efficacy must be accompanied by a precise and detailed knowledge of both compliance and administrative costs. The majority of developed countries try their best to reduce these costs, increasingly due to the complexity of taxation systems, to some reasonable, acceptable level.

No precise calculation of these costs exist in Croatia as yet. Brčić and Jančiev (1997*) have roughly estimated taxation costs to be HRK 6.6 in 1994. 9.2 in 1995, and HRK 9.7 in 1996 at every HRK 1,000 of tax collected. The costs have been increasing, especially in 1995 with regard to 1994. The rise coincides, however, with employment of new tax officers and introduction of new taxes. The average costs during the last three years were HRK 8.6 at every HRK 1,000 collected. Without further evaluation and comparisons with other countries, however, it is difficult to say whether such costs are high or low.

Kraft $\left(1997^{*}\right)$ therefore suggests further detailed investigation of compliance costs in Croatia. It is imperative to estimate the costs of (1) general sales tax which brings in the major part of budget revenue, (2) income tax which is the second important, and (3) to 
compare the costs of sales tax compliance with the same kind of costs in VAT. Carefully conceived and appropriate research could reduce the tax burden and even improve the public perception of tax administration. Research can well be expected to reveal too high a burden on tax authorities and an insufficient burden on taxpayers with regard to other countries where tax administrations were reduced and who make use of more tax exemptions than Croatia.

\section{(12) Prevention of tax evasion}

Tax evasion has become major problem even in countries with the most developed tax administrations and with the best of prevention mechanisms. Research on tax evasion in Croatia (Madžarević 1997) indicates its alarmingly high extent and tendencies. Even more alarming are socio-cultural aspects and the public attitude towards tax evasion (Štulhofer 1997). Since it is always more advisable to prevent the causes than to punish for the consequences, Croatian tax administration would be well advised to, together with everything said before, mind the following:

1. The taxation system should have as few exemptions, deductions and allowances as possible. This should be paid special attention in introducing value added tax, and passing special laws on certain categories of the public, regions, industries, etc. (i.e. liberated territories, islands, disabled persons, free-lance artists).

2. As efficient control and supervision system as possible is necessary, especially of the largest enterprises, along with the institution of special units for large enterprises if possible.

3. The penalty system must be regularly examined and adequate publicity given to any penalty increase. Since tax evasion in Croatia makes reputation of evaders better and not worse (Štulhofer 1997), too much should not be expected from disgracing tax evaders. A better solution might be punishing the really biggest perpetrators at the very top of political power. This would also re-establish trust in the impartiality of political institutions. Political motives should not be allowed to influence decisions here so that there can be no accusation of political cleansing.

4. The Tax Administration should also do its best to influence cutting down any public expenditure which may seem wasteful, unjustifiable or unfair.

5. The reputation and impartiality of the Tax Administration should be constantly strengthened and so show its focus on taxpayers. Special public relation services should be organised with this aim in mind. 
6. Special ID taxpayer numbers are very useful in preventing tax evasion. Since such numbers already exist in Croatia, co-ordination with courts of justice should be improved with the aim of obliging them to send data to Tax Administration regularly.

7. Regular assessment and monitoring of tax evasion in all relevant taxes is necessary.

8. A socio-cultural analysis of tax evasion would also seem to be valuable and its results should be compared with the results of the Tax Administration control and supervision services. 


\section{REFERENCES}

Andic, Suphan (1994) Organizational Dimensions of Public Finance in Transition Economies: An Assessment of the Recent Literature. In: Salvatore Schiavo-Campo (ed.) Institutional Change and the Public Sector in Transitional Economies. Washington: World Bank

Arbutina, H. (1997*) Neka pitanja normativnog uređenja i reforme porezne administracije u Hrvatskoj

Arndt, Hans-Wolfgang (1988) Grundzüge des Algemeinen Steuerrechts, München: Verlag Vahlen.

Aspe Armnella, P. (1993) Stabilisation and structural change: The Mexican experience, Lionel Robbins Lectures, LSE, London, MIT Press

Atkinson, Anthony, B. and Stiglitz, Joseph, E. (1980) Lectures on Public Economics. New York: McGraw-Hill

Bahl, Roy and Linn, Johannes, F. (1992) Urban Public Finance in Developing Countries. New York: Oxford University Press

Bawly, D. (1982) The subterranean economy, New York: McGraw-Hill

Bejaković, P. (1997*) Prikaz iskustava poreznih uprava u odabranim zemljama

Benjamini, Yael - Maital, Shlomo (1985) Optimal Tax Evasions and Optimal Tax Evasions Aspects - Behavioral Aspects. In: Gaertner, Wulf; Wenig, Alois (eds): The Economics of the Shadow Economy, Springer, Heidelberg, pp. 245-264.

Bird, Richard M. and Oldman, Oliver (eds.) (1990) Taxation in Developing Countries, 4th ed., Baltimore and London: The Johns Hopkins University Press.

Bird, Richard, M. (1989) The Administrative Dimension of Tax Reform in Developing Countries. In: Gillis, Malcolm (eds.) Tax Reform in Developing Countries. Durham i London: Duke University Press

Bird, Richard, M. (1991) Tax Administration and Tax Reform: Reflections on Experience. In: Khalilzadeh-Shirazi, Javad and Shah, Anwar (eds.), Tax Policy in Developing Countries. Washington, D.C.: The World Bank

Bird, Richard, M.and Wallich, Christine, I. (1994) Local Government Finance in Transition Economies: Policy and Institutional Issues. In: Schiavo-Campo, S. (ur.), Institutional Change and the Public Sector in Transitional Economies. Washington, D.C.: The World Bank

Bird, Rrichard M. (1990) Expenditures, Administration and Tax Reform in Developing Countries. International Burreau of Fiscal Documentation Bulletin, 44(6) : 263-267

Bolderson, Sarah, and Huiskes, Theodor (1994) Meeting Tax Obligations in Central and Eastern Europe. Bulletin for International Fiscal Documentation 48(12): 648-654. 
Bouckaert, Geert (1993) Governance between Legitimacy and Efficiency: Citizen Participation in the Belgian Fire Services. In: Jan Kooiman (ed.) Modern Governanance: New Government Society Interactions. London, Thousand Oaks, New Delhi: SAGE Publications

Brand, Phil (1996) Compliance: A 21st Century Approach. National Tax Journal, 49(3): 413-419

Brčić, R. and Jančiev, Z. (1997*) Analiza sadašnje porezne uprave u Republici Hrvatskoj

Bubaš, Zoran and Dalić, Martina (1996) Hrvatski zakon o porezu na dodanu vrijednost u kontekstu zahtjeva Europske unije. Financijska praksa, 20(2):139-155

Budge, J. and McKay, D. (1994) Developing Democracy, London, SAGE Publications Ltd.

Burges, R.and Stern, N. (1993) Taxation and Development. Journal of Economic Literature, $31(2): 762-830$

Busse, Volker (1996/97) Aufbau der Bundesverwaltung. In: Klaus König, Heinrich Siedentopf (Hrsg) Öffentliche Verwaltung in Deutschland. Baden-Baden: Nomos Verlagsgesellschaft

Byrne, Peter D. (1995) Overview of Privatization in the Area of Tax and Customs

Administration. Bulletin for International Fiscal Documentation 49(1): 10-16

Casanegra de Jantscher, M.and Bird, R. (eds.)(1992) Improving Tax Administration in Developing Countries, Wsahington D.C.: International Monetary Fund

Casanegra de Jantscher, Milka and Bird, Richard M.(1992) The Reform of Tax Administration, In: Casanegra de Jantscher, Milka and Bird, Richard M. (eds.) Improving Tax Administration in Developing Countries. Washington: IMF.

Casanegra de Jantscher, Milka; Silvani, Carlos and Vehorn, Charles, L. (1992) Modernizing Tax Administration. In: Tanzi, Vito (eds.), Fiscal Policies in Economies in Transition. Washington, D.C.: International Monetary Fund

CEEB (1996) Organisation of the Polish Tax Administration, Third Conference of Tax Administration of Central Eastern Europe and Baltic Countries (CEEB), Warsaw, October 28-31 1996

Central Office of Information (1971) The Central Government of Britain (1971) London: Central Office of Information

Chu, K.and Schwartz, G. (1994) Output Decline and Government Expenditures in European Transition Economies, IMF Working Paper 94/68

Cijan, Rafael and Grafenauer, Božo (1993) Državna uprava Republike Slovenije : posebni del. Maribor : Visoka Pravna Šola

Clague, C. and Rausser, C.R. (eds.)(1992) The Emergence of Market Economies in Eastern Europe, Cambridge, MA etc. :Blackwell

Cohen, John and Peterson, Steve (1996) Administrative Decentralization Strategies for the 1990s and Beyond. (Unpublished manuscript prepared by the Division for Public Administration and Development Management, United Nations Secretariat, forthcoming) 
Corfmat, F. (1985) Computerizing revenue administration in LDCs. Finance and Development, $22(3): 45-47$

Cowel, F. (1990) Cheating the Government, The Economics of Evasion, The MIT Press, Cambridge, Massachusetts, London.

Dahlgren, S. (1995) A Fiscal History of Sweden, The Swedish Tax Administration, The National Tax Board, Stockholm

Denhardt, Robert B. (1992) Issues in Public Administration Theory, In: Denhardt, Robert B. and Hammond, Barry R. (eds.) Public Administration in Action. Pacific Grove: Brooks/Cole Publishing Company

Đerek, B. (1984) Kaznena odgovornost za povrede poreznih propisa, Institut za javne financije Zagreb.

Dillinger, William (1995) Decentralization, Politics and Public Services. Economic Notes. No. 2, World Bank Country Department I, Latin America Region, Washington, D.C.: The World Bank

Dokumentacija Ministarstva financija RH, Porezna uprava, Odjel za porezne evidencije i statistiku, Zagreb, ožujak 1997.

Duncan, Harley T. and McLure, Charles E., Jr. (1997) Tax Administration in the United States of America: A Decentralized System. Bulletin for International Fiscal Documentation 51(2) : 74-85.

Đurić, Đ. (1994) Poslovi i ustrojstvo porezne uprave. Informator, br. 4176 od 16. 3.

DZS (1996) Statistički ljetopis. Zagreb: Državni zavod za statistiku.

Edwards, S. (1992) Stabilization and Liberatization Policies for Economies in Transition: Latin America Lessons for Eastern Europe, in Clague and Rausser, (eds.)(1992).

Edwards, S.and Edwards, A.C. (1991) Monetarism and Liberatization, The Chilean Experiment, Chicago, IL : Univerity of Chicago Press

Eichhorn, Peter; et al. (1985) Verwaltungslexikon. Baden-Baden : Nomos Verlagsfgesellschaft

Farioletti, Marius (1973) Tax Administration Funding and Fiscal Policy. National Tax Journal. 26 (1) : $1-16$

Fishlow, Albert and Friedman, Jorge (1994) Tax Evasion, Inflation and Stabilization. Journal of Development Economics, 43 (1) : 105-123

Frampton, Dennis (1993) Practical Tax Administration, Bath: Fiscal Publications.

Franičević, V. (1997) Politička ekonomija neslužbenog gospodarstva -Država i regulacija, Projekt Neslužbeno gospodarstvo u Republici Hrvatskoj, Financijska praksa 21(1-2):295-314.

Frank, Martin (1996/97) Aufbau der Landesverwaltung, U: Klaus König, Heinrich Siedentopf (Hrsg) Öffentliche Verwaltung in Deutschland. Baden-Baden: Nomos Verlagsgesellschaft. 
Frederickson, H. George (1980) New Public Administration. Alabama: The University of Alabama Press.

Frederickson, H. George (1989) Changing Epochs of Public Administration. Public Administration Review, 49 (2) : 95-100

Galbraith, J.K. (1965) Economic Development, Cambridge, Mass : Harvard University Press

Goode, R. (1990) Some Economic Aspect of Tax Administration. In: Bird and Oldman (eds.)

Taxation in Developing Countries, Baltimore etc. : The John Hopkins Univerity Press

Greider, William (1991) Tajne hrama: Kako Federalne rezerve vode SAD, Zagreb: Globus

Gunn, Alan and Ward, Larry D. (1988) Cases, Text and Problems on Federal Income Taxation, St. Paul : West Publishing Co.

Hamaekers, Hubert (1992) Taxation vis-a-vis trends in the world economy : summary of presentations and discussions at the 26th CIAT General Assembly, IBFD Bulletin, 46(12) : 571575

Hanžeković, Marijan (1960) Privredni sistem FNRJ, Zagreb, Narodne novine

Hanžeković, Marijan (1992) O reformi hrvatskog fiskalnog sustava. Financijska praksa, 16 (7-8) : 369-379

Hancock, D. (1996) Taxation Policy \& Practice, 1995/6 edition, London : Chapman \& Hall

Hansson, I.(1982) The Underground Economy in a High Tax Country: The Case of Sweden. In: Tanzi, Vito (ed) The Underground Economy in the United States and Abroad, Lexington Books, D.C. Heath and Co. Lexington, Massachusetts.

Harberger, Arnold (1988) Policymaking and Economic Policy in Small Developing Countries. In: Dornbusch, Rudiger and Helmers, F.L.C. (eds.)(1988) The Open Economy, Tools for Policymakers in Developing Countries, Oxford, Oxford University Press, pp 249-267

Harberger, Arnold (1989) Lessons of Tax Reforms from the Experience of Urugvay, Indonesia and Chile. In: Gillis, Malcolm (ed.) Tax Reforms in Developing Countries, Durham, NC : Duke University Press

Heady, Ferrel (1991) Public Administration : A Comparative Perspective. New York, Basel, Hong Kong: Marcel Dekker, Inc.

Henry, David (1995) Reform of a Major Service Delivery Agency - Not Platitudes But Action. Adminstration, 43(1)

Herkov, Zlatko (1935) Za reformu porezne administracije, Financijski arhiv, 5(7/8) : 227-282

Herkov, Zlatko (1936) Za reformu porezne administracije, Financijski arhiv, 6(4/5) : 109-112

Herkov, Zlatko (1938) Općinski proračuni u teoriji i praksi. Zagreb : Merkantile. 
Herkov, Zlatko (1939) Zakonitost u radu financijskih organa je preduslov valjane financijske uprave. Financijski arhiv, 9(2-3) : 37-39

Herkov, Zlatko (1940) Još o reformi porezne administracije. Financijski arhiv, 10(5-6) : 217-220

Herkov, Zlatko (1940) O financijalnoj samostalnosti banovine Hrvatske. Financijski arhiv, 10(8) : $355-362$

Herkov, Zlatko (1945) Obćinske financije. Zagreb : Gospodarstvo

Hesse, J.J. (ed.) (1993) Administrative Transformation in Central and Eastern Europe, Towards Public Sector Reform in Post-Communist Societies, Oxford etc. : Blackwell Publishers

Hy, Ronald, Jon and Waugh, William, L. (1995) State and Local Tax Policies, A Comparative Handbook. Westport, Connecticut and London: Greenwood Press

HZRFD (1996) Porezi - Zbirka mišljenja Ministarstva financija Republike Hrvatske. Zagreb : Hrvatska zajednica računovođa i financijskih djelatnika.

IBFD (1996) International Tax Glossary, revised 3rd ed. Amsterdam : International Bureau of Fiscal Documentation

IBFD (1996) Tax Administration has duty of care in investigating secret commissions In: European Taxation Database.

Ilersic, A. R. et.al. (1979) Tax Avoision. London: The Institute of Economic Affairs International Monetary Fund (1990) Government Finance Statistic Yearbook 1990, Washington, D.C.

Ivanišević, Stjepan et al. (1987) Uprava i društvo. Zagreb: Institut za društvena istraživanja Sveučilišta u Zagrebu

James, Simon and Wallschutzky, Ian G. (1995) The Shape of Future Tax Administration. Bulletin for International Fiscal Documentation, 49(5) : 210-218

Jašić, Zoran (1980) Budžet i privredni razvoj, Zagreb: Narodne novine

Jelčić, Božidar (1985) Razvoj javnih financija u Jugoslaviji. Zagreb : Pravni fakultet

Jelčić, Božidar (1988) Nauka o financijama i financijsko pravo. Zagreb : Informator

Jelčić, Božidar (1993) Kakav novi porezni sustav, Računovodstvo i financije, 39(6) : 43-45

Jelčić, Bo. (1993) Otpor plaćanju poreza, Financijska praksa 17(1):29-47.

Jelčić, Bo. (1994) Financijsko pravo i financijska znanost, Birotehnika, CDO, Zagreb

Jelčić, Bo. - Lončarić-Horvat, O. - Šimović, J. - Arbutina, H. (1996) Financijsko pravo -posebni dio, Birotehnika CDO, Zagreb,

Jenkins, G.P. (1992) Economic Reform and Institutional Innovation, International Burreau of Fiscal Documentation Bulletin, 46(12) : 588-596 
Jenkins, Glenn P. (1994) Modernization of Tax Administrations: Revenue Boards and Privatization as Instruments for Change. Bulletin for International Fiscal Documentation 48 (2) : $75-81$

Jurković, Pero (1989) Fiskalna politika u ekonomskoj teoriji i praksi. Zagreb : Informator.

Jurlina-Alibegović, D. (1997*) Fiskalna decentralizacija porezne administracije: odnosi nadležnosti

Kaldor, N. (1980) The Role of Taxation in Economic Development. Essays on Economic Policy I, London, Duckworth

Kay, J.A. and King, M.A. (1990) The British Tax System. Oxford : Oxford University Press.

Kesner-Škreb, M. (1996) Izuzeća od plaćanja poreza na dodanu vrijednost. Financijska praksa 20(2) : 169-178.

Khalilzadeh-Shirazi, Javad and Shah, Anwar (1991) Tax Policy in Developing Countries. Washington, D.C.: The World Bank

Klöti, Ulrich (1988) Switzerland, in Donald C. Rowat (ed.) Public Administration in Developed Democracies. New York and Basel: Marcel Dekker, Inc.

kontekstu zahtjeva Europske Unije. Financijska praksa, 20(2) : 139-154

Koprić, I. (1997*) Neka temeljna pitanja organizacije Porezne uprave Hrvatske

Koprić, Ivan (1993) Razna shvaćanja o organizaciji. Zbornik Pravnog fakulteta u Zagrebu 43(5) : $551-576$

Kornai, J. (1990) The Affinity Between Ownership Forms and Coordination Machanisms: The Common Experience of Reform in Socialistic Countries. Journal of Economic Perspectives, 4 (3):131-147

Kraft, E. (1997*) Troškovi ispunjavanja porezne obveze: Tema i u Hrvatskoj?

Kregar, Josip and Pavić, Željko (1987) Kadrovi u republičkoj upravi SRH, in Stjepan Ivanišević, et al. Uprava i društvo. Zagreb: Institut za društvena istraživanja Sveučilišta u Zagrebu

Kregar, Josip and Šimonović, Ivan (1996) Teorijski temelji ekonomske analize prava. Zagreb: Zbornik Pravnog fakulteta u Zagrebu, br. 6.

Leitner, Alfred (1939) Uvod u studiju poreznog prava. Zagreb : Narodne novine.

Lončarić-Horvat, O. (1996) Sustav posrednih poreza. In: Jelčić,Bo. - Lončarić-Horvat, O. Šimović, J. - Arbutina, H. (1996).

Ludwig-Mayerhofer, Wolfgang (1996) The Public and Private Sectors in Germany: Re-thinking Developments in German Penal Control. International Journal of the Sociology of Law 24(3): 273-290.

Lunaček,V. and Škarić, M. (1931) Zbornik zakona o neposrednim porezima. Zagreb : Obnova 
Madžarević, Sanja (1997) Porezna evazija.Financijska praksa, 21(1-2) : 241-258

Mansfield, Charles Y. (1990) Tax Reform in Developing Countries, The Administrative Dimension. International Burreau of Fiscal Documentation Bulletin, 44(3) : 137-143

Mansfield, Charles, Y. (1988) Tax Administration in Developing Countries, An Economic Perspective. International Monetary Fund Staff Papers. 35(1) : 181-197

March, James G., Johan P. Olsen (1995) Democratic Governance. New York etc.: The Free Press. Mason, R., Calvin, L. (1984) Public Confidence and Admitted Tax Evasion. National Tax Journal, 37(4) : 489-496

McCaffery, Edward J. (1990) The Holy Grail of Tax Simplification, Wisconsin Law Review, No. 5 .

McLure, C.E.Jr. et al. (1995) Tax Policy in Central Europe, International Centre For Economic Growth.

Messere, Ken C. (1993) Tax Policy in OECD Countries, Amsterdam: International Bureau of Fiscal Documentation.

Metcalfe, Les (1993) Public Management: From Imitation to Inovation, In: Jan Kooiman (ed.) Modern Governanace: New Government - Society Interactions. London, Thousand Oaks, New Delhi: SAGE Publications.

Miličić, Vjekoslav (1996) Opća teorija prava i države, I svezak, Učenje o sadržajima prava, III. izmijenjeno i dopunjeno izd., Zagreb : Pravni fakultet

Moe, Ronald C. and Robert S. Gilmour (1995) Rediscovering Principles of Public Administration : The Neglected Foundation of Public Law. Public Administration Review 55(2): 135-146.

Murray, M. (1995) Sales Tax Compliance and Audit Selection. National Tax Journal , 48 (4) : 515-530

Musgrave, Richard (1991) Tax Policy for the Transition. U: OECD (1991) The Role of Tax Reform in Central and Eastern European Economies. Paris

Musgrave, Richard i Musgrave, Peggy (1988) Javne financije u teoriji i praksi. Zagreb: Institut za javne financije

National Tax Administration (1992) An Outline of Japanese Tax Administration, Japan

Newbery, David, M.G. and Stern, Nicholas, H. (eds.)(1987) The Theory of Taxation for Developing Countries. New York: Oxford University Press

Oates, Wallace, E. (1972) Fiscal Federalism. New York, etc. : Harcourt Brace Jovanovich, Inc. OECD (1988) Administrative Responsiveness and the Taxpayers. Public Management Studies, No. 2, Paris 
OECD (1990) Taxpayers ' Rights and Obligations - A Survey of the Legal Situtation in OECD Countries. Paris

Ott, K. (1996) Hrvatska porezna reforma u kontekstu svjetskih poreznih reformi. Financijska praksa, 20 (2) : 139-154

Ott, K. (1996a) Zaključci, ocjene i preporuke u vezi s uvođenjem poreza na dodanu vrijednost u Republici Hrvatskoj (summary), Financijska praksa 20 (2): 243-253

Ott, K. (1997) Gospodarska politika i neslužbeno gospodarstvo, Financijska praksa 21 (1-2): 2944

Ow, A.S.S. (1992) Developments in Tax Administration in Singapore. 9th Asian-Pacific Tax Conference, Asian-Pacific Tax and Investment Research Centre, Singapore

Owens, J. and Whitehouse, E. (1996) Tax reform for the 21st century. IBFD Bulletin 50 (11-12) : 538-548

Peacock, A. (1991) Designing Tax Reform: Identifying the Problem. In: OECD (1991) The Role of Tax Reform in Central and Eastern European Economies, Paris

Polish Tax Policy and Tax Administration (1996), Tax '96, Warsaw.

Pommerehne, Werner, W. and Weck-Hannemann, Hannelore (1995) Tax Rates, Tax

Administration and Income Tax Evasion in Switzerland. Amsterdam: Kluwer Academic Publishers

Prud'homme, Remy (1995) The Dangers of Decentralization. The World Bank Research Observer. $10(2): 201-220$

Pugh, Derek (1976) The 'Aston' Approach to the Study of Organizations. In: Geert Hofstede, M. Sami Kassem (eds.) European Contributions to Organization Theory. Assen/Amsterdam: Van Gorcum.

Pusić, Eugen (1985) Upravni sistemi 1. Zagreb: Grafički zavod Hrvatske i Pravni fakultet u Zagrebu.

Pusić, Eugen (1993) Pojava javnog menadžmenta u razvoju suvremene uprave. U: Poduzetništvo i javni management u upravi Republike Hrvatske (zbornik radova). Zagreb:

Hrvatsko udruženje managera Croma, etc.

Pusić, Eugen (1994) Sustav državne uprave u Republici Hrvatskoj, Financijska praksa, 18(5) : 463-484

Pusić, Eugen (1995) Poslovi uprave. Financijska praksa 19(1): 3-20.

Pusić, Eugen (1996) Nauka o upravi. Zagreb: Školska knjiga.

Quintana, F. (1986) The Organization of Tax Administration in the CIAT Members Countries CIAT Review in 1985-1986, Technical Publication of the Inter-American Centre of Tax Administrators 
Reckers, P., Sanders, L., Roark, S. (1995) The Influence of Ethical Attititudes on Taxpayers Compliance. National Tax Journal, 48 (4) : 825-836

Roller, Dragan (1992) Kako onemogućiti fiskalni kriminalitet, Financijska praksa 16(7-8):455464.

Roller, Dragan (1996) Fiskalna politika u teoriji i praksi. Zagreb: Informator

Rondenelli, Dennis, A. (1981) Government Decentralization in Comparative Perspective: Theory and Practice in Developing Countries. International Review of Administrative Sciences, 61(2) : 133-146

Rose, M. and Wiswesser, R. (1995) Promjena cjelokupnog poreznog sustava u smjeru neutralnosti u odlučivanju i efikasnosti - iskustva stečena sudjelovanjem u hrvatskoj poreznoj reformi devedesetih godina, Financijska praksa, 19 (4): 301-316

Rosenbloom, David H. (1993) Public Administration : Understanding Management, Politics, and Law in the Public Sector. New York, etc.: McGraw-Hill

Sandford, Cedric (1997) "Policies Dealing with Tax Evasion". Paper presented at the International Workshop "The Importance of the Unofficial Economy in Economic Transition" Zagreb : Institute of Public Finance, May 1997

Sandford, C.; Godwin, M. and Hardwick, P. (1989) Administrative and Compliance Costs of Taxation, Bath : Fiscal Publication.

Sandford, Cedric (1993) Successful Tax Reform: Lessons from an Analysis of Tax Reform in Six Countries. Bath: Fiscal Publications

Sandford, Cedric (1994) International Comparison of Administrative and Compliance Costs of Taxation. Australian Tax Forum, $11: 291-309$

Sandford, Cedric (ed.) (1995) More Key Issues in Tax Reform. Bath : Fiscal Publications

Sandford, Cedric (ed.) (1995) Tax Compliance Costs: Measurement and Policy. Bath : Fiscal Publications

Schiavo-Campo, Salvatore (1996) Reforming The Civil Service. Finance and Development, 33(3) :10-13

Schiavo-Campo, Salvatorte (1994) Institutional Change and the Public Sector in Transitional Economies, Washington D.C., International Monetary Fund

Siedentopf, Heinrich (1988) Western Germany, In: Donald C. Rowat (ed.) Public Administration in Developed Democracies. New York and Basel: Marcel Dekker, Inc.

SII (1995) Servicio de Impuestos Internos/SII. Santiago de Chile

Silvani, C. (1992) Improving Tax Compliance. In: Casanegra de Jantscher and Bird, (eds.)(1992): Improving Tax Administration in Developing Countries, Washington, D.C. : International Monetary Fund 
Silvani, Carlos (1993) The Outlook for Tax Administration, Washington, D.C. :International Monetary Fund, Fiscal Affairs Department

Šimović, J. (1994) Nadzor nad financijskim poslovanjem javnog sektora u Republici Hrvatskoj, Porezni vjesnik, 3(10-11):9-12.

Skolka, Jiri (1987) A Few Facts about the Hidden Economy. In: Alessandrini, S. and Dallago, B. (eds): The Unofficial Economy (Andershot, Gower) 35-60.

Skorupan, V. (1997) Pravni aspekti neslužbenog gospodarstva, Projekt Neslužbeno gospodarstvo u Republici Hrvatskoj, Financijska praksa 21(1-2):329-346.

Sladović, Eugen (1933) Laički element u poreznom pravu. Financijski arhiv, 3(10-11) : 429-431

Sladović, Eugen (1934) Kontrola u poreznom pravu. Financijski arhiv, 4(6) : 285-299

Sladović, Eugen (1938) Novo pravno uređenje ispitnih propisa za višu financijalnu službu u Austriji. Financijski arhiv, 8(2-3) : 77-81

Sladović, Eugen (1939) Odgovornost i jamstvo privrednih savjetnika. Financijski arhiv, 9(4-5) : $52-60$

Sladović, Eugen (1940) Privredna i porezna kontrola i revizija. Financijski arhiv, 10(12) : 539548

Središnji ured Porezne uprave (1997) Obavljanje nadzora temeljem Zakona o Poreznoj upravi uputa, Porezni vjesnik, 6(2a):3-48.

Štulhofer, Aleksandar (1997) Sociokulturni aspekti neslužbenog gospodarstva - između oportunizma i nepovjerenja, Financijska praksa 21 (1-2): 125-140

Štulhofer, Aleksandar (1997) Politička ekonomija neslužbenog gospodarstva--sociokulturna dimenzija i porezna evazija. Financijska praksa, 21(1-2) : 277-294

Swedish Ministry of Finance, Tax Department (1996) An Outline of the Swedish Tax Administration, Stockholm

Tait, A. (1988) Value Added Tax: International Practice and Problems, Washington D.C., IMF

Tait, Alan, A., Gratz, Wilfred, L.M., and Eichengreen, B.J. (1979) International Comparisons of Taxation for Selected Developing Countries. International Monetary Fund Staff Papers. 26 (1) : $123-157$

Tanzi, Vito (1981) Tax Policy in Middle-Income Countries: Some Lessons of Experience. Washington, D.C. : International Monetary Fund

Tanzi, Vito (ed.) (1991) Fiscal Policies in Economies in Transition, Washington, D.C. : International Monetary Fund

Tanzi, Vito (1991a) Mobilization of Savings in Eastern European Countries: The Role of the State. In: Atkinson, B.A.; Brunetta, R. (1991) Economics for the New Europe, London, Macmillan 
Tanzi, V. and Pellechio, A. (1995) The Reform of Tax Administration, IMF WP/95/22, February, Washington: IMF

Tanzi, Vito (1995a) Fiscal Federalism and Decentralization: A Review of Some Efficiency and Macroeconomic Aspects. Annual Bank Conference on Development Economics, Washington, D.C., May 1-2 1995., Washington, D.C.: The World Bank

Terkper, S.E. (1994) Improving the Accountancy Content of Tax Reform in Developing

Countries, International Bureau of Fiscal Documentation Bulletin, 48(1) : 21-32

Tičarić, Matija (1906) Državna financijalna uprava, Budimpešta, Stephaneum.

Tiebout, Charles, M. (1956) A Pure Theory of Local Expenditures. The Journal of Political Economy. 54 (5) : 416-425

Tipke, Klaus and Lang, Joachim (1994) Steuerrecht, 14. völlig überarbeitete Auflage, Köln: Verlag Dr. Otto Schmidt

Tišma, Tošo (1974) Kontrola financijskog poslovanja, Zagreb, Informator

Tkalec, Dragutin (1977) Praksa uprava prihoda. Financijska praksa, 1(7) : 85-91

Vázquez-Caro, Jaime (1996) Assessing the Impact of Integrating Functions of Tax Administration on Efficiency and Effectiveness, contribution to the III International Conference on Tax Administration Issues in the Central Eastern and Baltic Countries, Warsaw, Poland, October 28-30, 1996.

Visković, Nikola (1981) Pojam prava, Prilog integralnoj teoriji prava, Split: Logos

Webley, P. et al. (1991) Tax Evasion: An Experimental Approach. Cambridge: Cambridge University Press

Wicks, J. (1966) Taxpayers' Compliance Costs from Personal Income Taxation. Iowa Business Digest, August, pp. 16-21.

Wildasin, David E. (1996) Introduction: Fiscal Aspects of Evolving Federations. International Tax and Public Finance 3(2): 121-135.

World Bank (1991) Lessons of Tax Reform, Washington, D.C., The World Bank

World Bank (1996) From Plan to Market, World Development Report 1996, Published for the World Bank, Oxford Univerity Press

Yaniv, G., (1995) A Note on the Tax-Evading Firm. National Tax Journal, 48 (1) : 113-120

Zakon o financijskoj policiji, "Narodne novine", br. 89/92., 94/93., 28/94.

Zakon o poreznoj upravi, "Narodne novine", br. 75/93.

**** (1938) 0bjašnjenje čl.12. Pravilnika za rad odsjeka računovodstva financijskih direkcija i za računovodno-blagajničko poslovanje poreznih uprava. Financijalni vijestnik, 48(1) : 40-41 
*** (1941) Financijalni priručnik, Zagreb : Narodne novine

**** (1974) Priručnik za inspektore prihoda. Zagreb : Institut za javne financije

**** (1982) Unapređenje organizacije i rada organa uprave za financije, Institut za javne financije, Zagreb.

*** (1989) Porez na dodanu vrijednost i fiskalni federalizam. Zagreb : Institut za javne financije

*** (1996) III International Conference on Tax Administration Issues in the Central Eastern and Baltic Countries, Warsaw, Poland, October 28-30, 1996.

*** (1996) The Land of the Free, The Economist, 21.2.96, str. 69-72

The sign * after the year defines the papers written for the research project "Development of Tax Administration in Croatia" published in "Financijska praksa", Volume 22, Number 1-2 ( April 1998). 